\title{
Efeitos na Fotossíntese e Área Foliar de Cultivares de Alface Inoculadas Mecanicamente com Patótipos do Lettuce mosaic virus e Lettuce mottle virus
}

\author{
Adriana S. Jadão ${ }^{1 * *}$, Marcelo A. Pavan ${ }^{1}$, Renate Krause-Sakate ${ }^{1}$ \& F. Murilo Zerbini ${ }^{2}$ \\ ${ }^{1}$ Departamento de Produção Vegetal, Universidade Estadual Paulista, Botucatu, SP, CEP 18603-970, fax: (14) 6802-7206, \\ e-mail: mapavan@fca.unesp.br; ${ }^{2}$ Departamento de Fitopatologia/BIOAGRO, Universidade Federal de Viçosa, Viçosa, MG, \\ CEP 36571-000, fax (31)3899-2240, e-mail: zerbini@ufv.br
}

(Aceito para publicação 26/08/2003)

Autor para correspondência: Marcelo A. Pavan

JADÃO, A.S., PAVAN, M.A., KRAUSE-SAKATE, R \& ZERBINI, F.M. Efeitos na fotossíntese e área foliar de cultivares de alface inoculadas mecanicamente com patótipos do Lettuce mosaic virus e Lettuce mottle virus. Fitopatologia Brasileira 29:011-015. 2004.

\section{RESUMO}

Levantamentos realizados no estado de São Paulo indicaram a ocorrência isolada e em infecções mistas do Lettuce mosaic virus (LMV) e do Lettuce mottle virus (LeMoV) em plantas de alface (Lactuca sativa). O presente trabalho teve como objetivo estudar os efeitos da infecção isolada e mista entre o LMV (patótipos II e IV) e o LeMoV, em cultivares de alface suscetível (White Boston) e tolerante (Elisa - gene $\mathrm{mol}^{l}$ ) ao LMV patótipo II. As plantas foram inoculadas via extrato vegetal tamponado com isolados de LMV-II, LMV-IV e LeMoV separadamente e em diferentes combinações, com intervalo de $24 \mathrm{~h}$ ou simultaneamente com os dois vírus. As plantas infetadas foram analisadas utilizando-se hospedeiras diferenciais para o LMV e o LeMoV, e no caso do LMV pelo teste sorológico de PTA-ELISA. Nas avaliações de peso fresco e seco, área foliar e teor de clorofila, observou-se que a cultivar White Boston foi a mais afetada por ambos os vírus. As infecções mistas e isoladas na cultivar Elisa causaram efeitos semelhantes, provavelmente devido a presença do gene $\mathrm{mol}^{1}$ de tolerância ao LMV-II. O isolado LMV-IV foi considerado o mais agressivo nestas cultivares quando comparado ao LMV-II e o LeMoV.

Palavras chave adicionais: mosaico da alface, mosqueado da alface, Lactuca sativa, Potyvirus.
Effects on photosynthesis and foliar area of lettuce cultivar mechanically inoculated with Lettuce mosaic virus pathotypes and Lettuce mottle virus

A survey of virus isolates causing mosaic in lettuce (Lactuca sativa) in the state of São Paulo, Brazil, indicated the occurrence of Lettuce mosaic virus (LMV) and Lettuce mottle virus (LeMoV) alone or in mixed infections. The objective of this work was to study the effects of single and mixed infections between LMV (pathotypes II and IV) and LeMoV in susceptible (White Boston) and tolerant (Elisa, $m o 1^{1}$ gene) lettuce cultivars. Plants were sap-inoculated with LMV-II,
LMV-IV and LeMoV, in single infections and in different combinations, with either a $24 \mathrm{~h}$ interval between the two viruses or simultaneously. Plants were tested for the presence of LMV and LeMoV using differential hosts and, in the case of LMV, the serological test (PTAELISA) was used. In the evaluations of fresh and dry weight, leaf area and chlorophyll content, the White Boston cultivar was observed to be the most affected by both viruses. This cultivar's response to single and mixed infections was similar, probably due to the presence of the $m o l^{l}$ gene which confers tolerance to LMV-II. When compared to LMV-IV and LeMoV, LMV-IV was the most aggressive isolate.

\section{INTRODUÇÃO}

A alface (Lactuca sativa L.) está entre as hortaliças de maior importância econômica no Brasil. O estado de São Paulo é o principal produtor, com uma área cultivada de aproximadamente 7.370 hectares e produção de 17.315 toneladas em 2001 (Agrianual, 2002).

As viroses podem ser responsáveis por perdas de até $100 \%$ em cultivos de alface, dependendo das condições ambientais e dos cuidados dispensados à cultura (Resende \& Cupertino, 1995).

\footnotetext{
*Parte da Dissertação de Mestrado do primeiro autor. FCA-UNESPBotucatu. (2001)

** Bolsista CAPES
}

O vírus do mosaico da alface (Lettuce mosaic virus, LMV), um dos vírus mais importantes em áreas de produção comercial de alface, encontra-se disseminado por todo o mundo, possivelmente devido ao intercâmbio de sementes infetadas (Dinant \& Lot, 1992). O LMV pertence ao gênero Potyvirus, família Potyviridae, e seu genoma é constituído por uma molécula de RNA de fita simples, senso positivo, poliadenilada, com 10.080 nucleotídeos (Revers et al., 1997). O LMV apresenta uma ampla gama de hospedeiros, infetando 121 espécies vegetais pertencentes a 60 gêneros e 17 famílias botânicas (Dinant \& Lot, 1992). A maioria das espécies hospedeiras encontra-se na família Asteraceae, a qual pertence a alface.

$\mathrm{O}$ vírus do mosaico da alface é transmitido por afídeos, pelas sementes de plantas infetadas e via extrato vegetal. A 


\section{A.S. Jadão et al.}

taxa de transmissão do vírus pelas sementes de alface varia de 1,33 a $16,5 \%$, de acordo com o isolado e cultivar utilizados (Dinant \& Lot, 1992; Jadão et al., 2002).

Além do LMV, levantamentos de campo realizados por Stangarlin (1995) indicaram que um segundo vírus provocando sintoma de mosqueado em alface (Lettuce mottle virus, LeMoV) é bastante prevalecente no estado de São Paulo, ocorrendo freqüentemente em infecção mista com o LMV. O LeMoV foi inicialmente descrito por Marinho et al. (1982) no Distrito Federal, infetando tanto cultivares imunes como resistentes ao LMV. Trata-se de um vírus de partículas isométricas com aproximadamente $30 \mathrm{~nm}$ de diâmetro, quando analisadas ao microscópio eletrônico (Marinho et al., 1986a). O LeMoV pode ser transmitido mecanicamente (Marinho et al., 1982) e pelo afídeo Hyperomyzus lactucae L. (Marinho et al., 1986b). Até o momento, informações sorológicas e moleculares são completamente desconhecidas para o LeMoV.

Algumas características biológicas e taxonômicas do LeMoV sugerem sua possível classificação no gênero Sequivirus, do qual faz parte um outro vírus muito similar, o Dandelion yellow mosaic virus (DaYMV), descrito infetando plantas de alface em diferentes países do continente europeu (Bos et al., 1983). Apesar de classificado na família Sequiviridae, gênero Sequivirus, nenhum dado molecular é conhecido para o DaYMV.

Os sintomas induzidos pelo LeMoV em alface incluem mosqueado e mosaico, semelhantes àqueles induzidos pelo LMV, cujos sintomas variam de acordo com o isolado viral, a cultivar de alface e as condições ambientais, ocasionando, normalmente, mosaico, nanismo, distorção e redução da área foliar. Necrose e morte de plantas podem ocorrer em certas combinações de isolados virais e cultivares de alface (Grogan, 1980; Zerbini et al., 1995; Krause-Sakate et al., 1999). Existe uma grande dificuldade na distinção desses dois vírus com base nos sintomas. Levantamentos de campo realizados no estado de São Paulo revelaram que frequentemente plantas de alface com sintoma de mosaico apresentavam muitas vezes o LeMoV e LMV em infecção mista (Stangarlin, 1995).

Em infecções mistas entre dois ou mais vírus freqüentemente ocorre o fenômeno de sinergismo, onde a severidade dos sintomas é maior do que a adição dos efeitos dos vírus isolados (Colariccio et al., 1991). Muitos casos de sinergismo envolvem espécies do gênero Potyvirus. Exemplos clássicos incluem a interação do Potato virus $X$ (PVX) com vários potyvírus, incluindo Potato virus $Y(\mathrm{PVY})$, Tobacco vein mottling virus (TVMV) e Tobacco etch virus (TEV), infetando espécies de Nicotiana e diversas outras solanáceas. Nesses casos, o aumento da severidade dos sintomas é relacionado com um aumento do acúmulo do PVX, não havendo aumento ou decréscimo da concentração do potyvírus (Vance, 1991).

Para a cultura da alface são poucos os trabalhos que estudaram a interação entre vírus. Walkey \& Payne (1990), observando a infecção mista envolvendo o LMV, Cucumber mosaic virus (CMV) gênero Cucumovirus, família Bromoviridae e Beet western yellows virus (BWYV) gênero
Polerovirus, família Luteovirus em alface, constataram a ocorrência de sintomas mais severos nas combinações que incluíam o LMV.

Devido à frequente ocorrência de infecção mista entre o LMV e o LMoV e à importância do LMV para a cultura da alface, o presente trabalho teve como objetivo o estudo dos efeitos à nível fotossintético e de área foliar da infecção entre diferentes patótipos do LMV e o LeMoV, em genótipos de alface.

\section{MATERIALEMÉTODOS}

\section{Obtenção e manutenção dos isolados virais}

Os isolados de LMV AF198 (patótipo II), AF199 (patótipo IV) e o isolado 197 do LeMoV utilizados neste estudo foram obtidos e identificados por Stangarlin (1995) por meio de testes biológicos, sorológicos e observações em microscopia eletrônica. Estes isolados foram mantidos in vivo por meio de inoculações mecânicas sucessivas via extrato vegetal tamponado (fosfato de sódio $0,05 \mathrm{M}, \mathrm{pH} 7,2$, para o LMV-II e -IV, e fosfato de sódio 0,05 M, pH 8,0, para o LeMoV, ambos contendo sulfito de sódio a $0,01 \mathrm{M}$ ) em plantas de Chenopodium quinoa (W.). Os isolados foram armazenados em folhas de C. quinoa desidratadas em $\mathrm{CaCl}_{2}$, mantidas à $20^{\circ} \mathrm{C}$.

\section{Instalação do experimento}

Conduzido em casa de vegetação, o experimento foi constituído de dez tratamentos por cultivar de alface (ELISAtolerante; White Boston-suscetível): 1 inoculação das testemunhas apenas com tampão fosfato de sódio $0,05 \mathrm{M}, \mathrm{pH}$ 7,0; 2 inoculação do LMV-II; 3 inoculação do LMV-IV; 4 inoculação do LeMoV; 5 inoculação do LMV-II e, após 24 h, do LeMoV; 6 inoculação do LeMoV e, após 24 h, do LMV-II; 7 inoculação do LMV-IV e, após 24 h, do LeMoV; 8 inoculação do LeMoV e, após 24 h, do LMV-IV; 9 inoculação do LMV-II e LeMoV simultaneamente; e 10 inoculação do LMV-IV e LeMoV simultaneamente. Cada um dos tratamentos foi composto por dez repetições, sendo que cada repetição foi constituida por uma planta de alface por vaso. As plantas foram inoculadas mecanicamente 20 dias após a semeadura, utilizando-se como inóculo plantas infetadas de C. quinoa (1 $\mathrm{g}$ de folhas para cada $4 \mathrm{ml}$ de tampão). A casa de vegetação foi mantida com uma temperatura em torno de $25^{\circ} \mathrm{C}$.

\section{Teste sorológico}

A técnica de "PTA-ELISA" ("plate-trapped antigen"), descrita por Mowart \& Dawson (1987) foi utilizada para confirmar a infecção pelo LMV nas plantas de alface inoculadas. No teste foram utilizadas amostras de $1 \mathrm{~g}$ de folhas de plantas com ou sem sintomas, coletadas 15 dias após a inoculação. Como controle negativo foram utilizadas amostras de plantas de alface sadias. As leituras foram realizadas em leitora BIOTEK modelo EL 307C, utilizando-se filtro para comprimento de onda de $405 \mathrm{~nm}$. As amostras foram consideradas infetadas quando o valor médio das leituras de 
Efeitos na fotossíntese e área foliar de cultivares de alface...

absorvância excedia em três vezes o valor médio das leituras das amostras sadias.

\section{Avaliação do peso fresco e seco, atividade fotossintética e área foliar}

As plantas com diagnóstico positivo para o LMV no teste de ELISA e com sintomas visíveis para o LeMoV foram avaliadas. Após 25 dias da inoculação, as plantas foram cortadas rente ao solo, identificadas e pesadas para se obter o peso fresco $(\mathrm{g})$. Duas folhas intermediárias de cada planta de alface foram retiradas, e a atividade fotossintética foi medida por meio da assimilação líquida de $\mathrm{CO}_{2}$ pela planta, em três pontos de cada uma das folhas (ponta, meio e base), utilizandose uma câmara portátil de fotossíntese (marca LI-COR, modelo LI-6200). Para a transformação das leituras feitas pelo aparelho foi utilizada a fórmula: $\mathrm{Y}=0,0996 \mathrm{x}(\mathrm{X}-0,152)$, onde $\mathrm{X}$ corresponde à leitura do aparelho $\mathrm{e} Y$ é igual ao teor de clorofila expresso em $\mathrm{mg} / \mathrm{cm}^{2}$. As mesmas duas folhas retiradas das plantas foram prontamente fotocopiadas e identificadas para avaliação da área foliar $\left(\mathrm{cm}^{2}\right)$. Nesta avaliação utilizou-se um medidor portátil (marca LI-COR, modelo LI-3000 A). Para avaliação do peso seco (g), as plantas foram armazenadas em sacos de papel, identificadas e mantidas em estufa durante cinco dias sob uma temperatura constante de $70^{\circ} \mathrm{C}$.

Os resultados obtidos foram submetidos à análise de variância de médias comparadas, por meio do teste de Tukey. Os dados foram transformados em SQRT $(x+0,50)$. As análises foram realizadas utilizando o programa ESTAT, da Universidade Estadual Paulista, Campus de Jaboticabal.

\section{RESULTADOS E DISCUSSÃO}

Os efeitos das diferentes combinações entre os vírus na atividade fotossintética, no peso seco e fresco e na área foliar das cultivares Elisa e White Boston são apresentados na Tabela 1.
A redução do teor de clorofila na cv. Elisa foi significativa somente para a inoculação isolada do LMV-IV. Este dado pode ser explicado pelo fato da cultivar Elisa possuir o gene recessivo mol $^{1}$ que confere tolerância ao isolado LMV-II (Pink et al., 1992). Nesta mesma cultivar foi verificada uma certa tolerância para o LeMoV que apresenta sintomas fracos, quase que imperceptiveis (Silva \& Pavan, 2001). E possível que essa tolerância seja devida à presença do gene $m o l^{1}$, entretanto, sabe-se que genes de resistência a vírus e fungos estão geneticamente próximos na alface (Witsenboer et al., 1995). Dessa forma, a tolerância pode ser devido à presença de outro gene ou QTL específico para o LeMoV e geneticamente próximo ao gene $\mathrm{mol}^{1}$. Essa hipótese deve ser testada por meio de inoculação de cultivares diferenciadoras de alface contendo diferentes combinações dos genes de resistência a LMV já identificados $\left(\mathrm{mol}^{1}, \mathrm{~mol}^{2}\right.$ e Mo2). Curiosamente, nas infecções mistas envolvendo o LMV-IV e o LeMoV, onde os efeitos do LMV-IV deveriam prevalecer, o teor de clorofila das plantas se manteve próximo ao da testemunha sadia e do LeMoV em infecção simples.

$\mathrm{Na}$ cv. White Boston, suscetível para os três vírus, a redução do teor de clorofila e da área foliar foi bastante evidente para o LMV-IV em infecção simples. Verificou-se que as plantas com infecção mista envolvendo LMV-IV e LeMoV, foram menos afetadas do que as plantas com infecção simples com o LMVIV, sugerindo um efeito atenuante do LeMoV sobre este patótipo do LMV. Os efeitos na área foliar na cultivar tolerante ELISA foram mais expressivos quando o LMV-IV foi inoculado sozinho ou em combinação com o LeMoV.

A redução do teor de clorofila das plantas pode estar algumas vezes relacionada à agressividade do isolado, uma vez que com o surgimento de sintomas como mosaico e necrose foliar, a atividade fotossintética é reduzida, devido à grande destruição de moléculas de clorofila nos locais com sintomas (Leite \& Pascholati, 1995). A redução no teor de clorofila foi

TABELA 1 - Avaliação do peso seco e fresco, área foliar e atividade fotossintética em plantas de alface (Lactuca sativa) das cultivares Elisa e White Boston infetadas com os patótipos II e IV do Lettuce mosaic virus (LMV) e do Lettuce mottle virus (LeMoV), separadamente e em diferentes combinações

\begin{tabular}{|c|c|c|c|c|c|c|c|c|}
\hline \multirow{2}{*}{ Tratamento } & \multicolumn{2}{|c|}{ Peso fresco $(g)^{*}$} & \multicolumn{2}{|c|}{ Peso seco $(g)^{*}$} & \multicolumn{2}{|c|}{ Área Foliar $\left(\mathrm{cm}^{3}\right)^{*}$} & \multicolumn{2}{|c|}{ Teor de clorofila $\left(\mathrm{mg} / \mathrm{cm}^{2}\right)^{t}$} \\
\hline & Elisa & W. Boston & Elisa & W. Boston & Elisa & W. Boston & Elisa & W. Boston \\
\hline 1 (Testemunha) & $16,49 \mathrm{a}$ & $21,28 \mathrm{a}$ & $1,87 \mathrm{a}$ & $2,65 \mathrm{a}$ & $18,51 \mathrm{a}$ & $37,49 \mathrm{a}$ & $1,8 \mathrm{a}$ & $1,6 \mathrm{a}$ \\
\hline 2 (LMV-II) & $16,08 \mathrm{a}$ & $17,92 \mathrm{ab}$ & $1,89 \mathrm{a}$ & $2,06 \mathrm{a}$ & $17,44 \mathrm{ab}$ & $31,47 \mathrm{ab}$ & $1,6 \mathrm{a}$ & $1,2 \mathrm{ab}$ \\
\hline 3 (LMV-IV) & $12,59 \mathrm{ab}$ & $13,08 \mathrm{~b}$ & $1,50 \mathrm{ab}$ & $1,81 \mathrm{a}$ & $13,44 \mathrm{bc}$ & $13,94 \mathrm{e}$ & $1,2 \mathrm{~b}$ & $0,8 \mathrm{~b}$ \\
\hline $4(\mathrm{LeMoV})$ & $14,43 \mathrm{ab}$ & $14,66 \mathrm{ab}$ & $1,52 \mathrm{ab}$ & $2,08 \mathrm{a}$ & $15,47 \mathrm{abc}$ & $23,01 \mathrm{bcd}$ & $1,7 \mathrm{a}$ & $1,4 \mathrm{a}$ \\
\hline 5 (LMV-II e LeMoV) $^{1}$ & $12,62 \mathrm{ab}$ & $16,09 \mathrm{ab}$ & $1,48 \mathrm{ab}$ & $2,17 \mathrm{a}$ & $15,58 \mathrm{abc}$ & $24,63 \mathrm{bc}$ & $1,6 \mathrm{a}$ & $1,4 \mathrm{a}$ \\
\hline $6{\text { (LeMoV e LMV-II })^{1}}^{1}$ & $12,39 \mathrm{ab}$ & $18,33 \mathrm{ab}$ & $1,42 a b$ & $2,71 \mathrm{a}$ & $14,70 \mathrm{abc}$ & $22,51 \mathrm{bcd}$ & $1,7 \mathrm{a}$ & $1,3 \mathrm{a}$ \\
\hline 7 (LMV-IV e LeMoV) $^{1}$ & $13,32 \mathrm{ab}$ & $21,16 \mathrm{a}$ & $1,49 a b$ & $2,89 \mathrm{a}$ & $14,91 \mathrm{abc}$ & 21,34 cde & $1,7 \mathrm{a}$ & $1,1 \mathrm{ab}$ \\
\hline 8 (LeMoV e LMV-IV) $^{1}$ & $11,16 \mathrm{~b}$ & $21,60 \mathrm{a}$ & $1,34 \mathrm{~b}$ & $2,53 \mathrm{a}$ & $12,31 \mathrm{c}$ & 21,41 cde & $1,5 \mathrm{a}$ & $1,2 \mathrm{ab}$ \\
\hline $9(\mathrm{LMV}-\mathrm{II} \text { e LeMoV})^{2}$ & $12,52 \mathrm{ab}$ & $20,88 \mathrm{a}$ & $1,55 \mathrm{ab}$ & $2,41 \mathrm{a}$ & $13,89 \mathrm{bc}$ & 20,74 cde & $1,7 \mathrm{a}$ & $1,2 \mathrm{ab}$ \\
\hline 10 (LMV-IV e LeMoV) $^{2}$ & $11,55 \mathrm{~b}$ & $16,99 \mathrm{ab}$ & $1,51 \mathrm{ab}$ & $2,21 \mathrm{a}$ & $12,97 \mathrm{c}$ & $15,26 \mathrm{de}$ & $1,5 \mathrm{a}$ & $1,2 \mathrm{ab}$ \\
\hline $\mathrm{CV}(\%)$ & 9,67 & 11,66 & 7,52 & 12,23 & 8,13 & 12,14 & 5,34 & 10,31 \\
\hline
\end{tabular}

${ }^{1}$ Plantas inoculadas com intervalo de 24 h entre um vírus e outro.

${ }^{2}$ Plantas inoculadas simultaneamente com os dois vírus.

* Médias seguidas de mesma letra na coluna não diferem entre si ao nível de 5\% de Probabilidade pelo Teste de Tukey. Cada valor representa uma média das plantas com diagnóstico positivo para os vírus, em cada tratamento. 
significativa para o LMV-IV, confirmando sua maior agressividade em comparação ao LMV-II e ao LeMoV.

Foi observada uma redução acentuada do peso fresco na cv. Elisa infetada simultaneamente pelo LeMoV e LMV-IV, em comparação à infecção isolada destes vírus. Entretanto, na cv. W. Boston não foi observada redução do peso fresco para esta combinação. Possivelmente este fato está ligado à tolerância observada ao LeMoV nesta cultivar. A redução de sintomas e danos, quando em infecção mista com LMV-IV e LeMoV na cv. Elisa, pode estar sendo influenciada pela taxa de replicação do LeMoV, reduzida pela presença de um gene de tolerância. Como a cv. W. Boston é suscetível a ambos os vírus, o efeito da interação entre o LMV-IV e LeMoV pode ser melhor evidenciado.

Não houve diferença significativa, nas duas cultivares, entre os tratamentos com intervalo de $24 \mathrm{~h}$ entre as inoculações, mostrando que a ordem de inoculacão dos vírus não interferiu no efeito destes nas plantas. Também foi observado, que prevaleceu nestas cultivares o caráter agressivo do patótipo IV do LMV.

A análise do fenômeno de sinergismo entre potyvírus e vírus pertencentes a outros gêneros demonstrou que a proteína HC-Pro, produzida pelos potyvírus, constitui um fator de patogenicidade, inibindo o mecanismo de silenciamento gênico pós-transcricional que é uma resposta de defesa do hospedeiro à infecção viral (Anandalakshimi et al., 1998; Brignetti et al., 1998; Kasschau \& Carrington, 1998). Nessas interações, os sintomas da infecção mista são mais acentuados do que os sintomas de cada vírus separadamente devido ao maior acúmulo do não-potyvírus (Pruss et al., 1997). Assim sendo, os maiores danos causados às plantas pelo LMV-IV quando em infecção simples comparado aos efeitos provocados pela infecção mista com o LeMoV sugerem um efeito atenuante do LeMoV sobre o LMV.

Em conjunto, os resultados sugerem que, diferente de outras infecções mistas envolvendo potyvírus estudadas até o presente, uma possível interação LMV/LeMoV pode estar envolvendo um descréscimo no acúmulo do potyvírus. É possível que algum fator produzido pelo LeMoV seja capaz de proteger a planta de uma infeção com o LMV, ou de gerar uma resposta de defesa mais eficiente da planta direcionada a esse vírus. Um estudo mais detalhado do mecanismo envolvido nessa interação pode levar a novas estratégias de controle de doenças causadas por potyvírus.

\section{AGRADECIMENTOS}

Os autores agradecem à Dra. Lilian Amorim (ESALQUSP) e à Dra. Rumy Goto (UNESP-Botucatu), pela atenção dispensada e disponibilidade dos equipamentos utilizados nas avaliações do experimento.

\section{REFERÊNCIAS BIBLIOGRÁFICAS}

AGRIANUAL 2001-Anuário da Agricultura Brasileira. São Paulo:Ed. Argos Comunicações:545. 2002.
ANANDALAKSHMI, R., PRUSS, G.J., GE, X., MARATHE, R., MALLORY, A.C., SMITH, T.H. \& VANCE, V.B. A viral suppressor of gene silencing in plants. Proceedings of the National Academy of Sciences 95:13079-13084. 1998.

BOS, L., HUIJBERTS, N., HUTTINGA, H. \& MAAT, D.Z. Further characterization of dandelion yellow mosaic virus from lettuce and dandelion. Netheland Journal Plant Pathology. 89:207-222. 1983.

BRIGNETI, G., VOINNET, O., LI, W.X., JI, L.H., DING, S.W. \& BAUCOMBE, D.C. Viral pathogenicity determinants are supressors of gene silencing in Nicotiana benthamiana. EMBO Journal 17:67396746. 1998.

COLARICCIO, A., BARRADAS, M.M. \& VICENTE, M. Interação do vírus da necrose branca do tomateiro com dois outros vírus que afetam o tomateiro: mosaico do fumo (TMV) e vira-cabeça (TSWV). Arquivo do Instituto Biológico 58:51-59. 1991.

DINANT, S. \& LOT, H. Lettuce mosaic virus. Plant Pathology 41:528542. 1992.

GROGAN, R.G. Control of lettuce mosaic with virus-free seed. Plant Disease 64:446-449. 1980.

JADÃO, A.S., PAVAN, M.A., SILVA, N. \& ZERBINI, F.M. Seed transmission of lettuce mosaic virus (LMV) pathotype II and IV in different lettuce genotypes. Summa Phytopatologica 28:58-61. 2002.

KASSCHAU, K.D. \& CARRINGTON, J.C. A counterdefensive strategy of plant viruses: Suppression of posttranscriptional gene silencing. Cell 95:461-470. 1998.

KRAUSE-SAKATE, R., LEGALL, O., PAVAN, M.A., ZAMBOLIM, E.M., CARVALHO, M.G. \& ZERBINI, F.M.. Systemic necrosis caused by two isolates of Lettuce mosaic virus (LMV) in lettuce (Lactuca sativa) cultivars possessing the Mo2 gene. Virus Reviews and Research 4:153. 1999. (Abstract)

LEITE, B. \& PASCHOLATI, S.F. Hospedeiro:Alterações fisiológicas induzidas por fitopatógenos. In: Bergamin, A., Kimati, H. \& Amorim, L. (Eds.) Manual de Fitopatologia - Vol. 1 - Princípios e Conceitos. São Paulo: Ed. Agronômica Ceres. 1995. pp.393-416.

MARINHO, V.L., KITAJIMA, E.W., LIN, M.T. \& COSTA, C.L. Caracterização do vírus do mosqueado da alface. Fitopatologia Brasileira 7:543. 1982. (Resumo)

MARINHO, V.L.A., LIN, M.T. \& KITAJIMA, E.W. Virus do mosqueado da alface-Um virus isometrico transmitido por afideo. Fitopatologia Brasileira 11:923-935. 1986a. (Resumo)

MARINHO, V.L.A., LIN, M.T. \& KITAJIMA, E.W. Purificação e sorologia do vírus do mosqueado da alface. Fitopatologia Brasileira 11:937-943. 1986a.

MARINHO, V.L.A., LIN, M.T. \& KITAJIMA, E.W. Vírus do mosqueado da alface-Um virus isometrico transmitido por afideo. Fitopatologia Brasileira 11:923-935. 1986b.

MOWART, W.P. \& DAWSON, S. Detection and identification of plant viruses by ELISA using crude sap extracts and unfractioned antisera. Journal of Virological Methods 15:233-247. 1987.

PINK, D.A.C., LOT, H. \& JOHNSON, R. Novel pathotypes of Lettuce mosaic virus: Breakdown of a durable resistance ? Euphytica 63:169-174. 1992.

PRUSS, G., GE, X., SHI, X.M., CARRINGTON, J.C. \& VANCE, V. Plant viral sinergism: The potyviral genome encodes a broad-range pathogenicity enhancer that transactivates replication of heterologous 
Efeitos na fotossíntese e área foliar de cultivares de alface...

viruses. Plant Cell 9:859-868. 1997.

RESENDE, J.A.M. \& CUPERTINO, E.P. Doenças em hortaliças. Informe Agropecuário, 18:18-27. 1995.

REVERS, F., LOT, H., SOUCHE, S., CANDRESSE, T., DUNEZ, J. \& LE GALL, O. Biological and molecular variability of Lettuce mosaic virus isolates. Phytopathology 87:397-403. 1997.

SILVA, N. \& PAVAN, A.M. Tolerância de cultivares de alface ao vírus do mosqueado da alface. Fitopatologia Brasileira 26:511. 2001. (Resumo).

STANGARLIN, O.S. Identificação dos vírus causadores de mosaico em cultivares de alface (Lactuca sativa L.) resistente ao vírus do mosaico da alface nas regiões produtoras do Estado de São Paulo. (Dissertação de Mestrado). Botucatu. Faculdade de Ciências Agronômicas/UNESP. 1995.
VANCE, V. Replication of Potato virus $X$ RNA is altered in coinfections with potato virus Y. Virology 182:486-494. 1991.

WALKEY, D.G.A. \& PAYNE, C.J. The reaction of two lettuce cultivars to mixed infection by Beet western yellow virus, Lettuce mosaic virus and Cucumber mosaic virus. Plant Pathology 39:156160. 1990.

WITSENBOER, H., KESSELI, R.V., FORTIN, M.G., STANGHELLINI, M. \& MICHELMORE, R.W. Sources and genetic structure of a cluster of genes for resistance to three pathogens in lettuce. Theoretical and Applied Genetics 91:178-188. 1995.

ZERBINI, F.M., KOIKE, S.T. \& GILBERTSON, R.L. Biological and molecular characterization of Lettuce mosaic potyvirus isolates from the Salinas Valley of California. Phytopathology 87:746-752. 1995. 